\title{
INITIAL DEVELOPMENT OF TWO EUCALYPTUS HYBRID SUBMITTED TO IRRIGATION
}

\section{GABRIEL Q. DE OLIVEIRA ${ }^{1}$, ADRIANO S. LOPES ${ }^{2}$, LEANDRO H. JUNG ${ }^{3}$, NORTON H. REGO$^{2}$, JEAN C. L. DE OLIVEIRA ${ }^{4}$}

\begin{abstract}
The eucalyptus offers several advantages compared to other forestry species and, by using the irrigation can increase productivity and decrease production time. The objective of the present study was to evaluate two hybrid eucalyptus (Grancam and Urograndis), no irrigation, dripping and micro sprinkler irrigated at 90, 120, 150 and 180 days after transplanting (DAT). The experiment was conducted at the experimental irrigation area in the State University of Mato Grosso do Sul, in the municipality of Aquidauna - State of MS, Brazil. The experimental design was randomized blocks, split plot with four blocks and two replications within each block, and the plots were composed by irrigation treatments (dripping, micro sprinkler irrigate and dry) and the subplots the hybrids (Grancam and Urograndis).The total area of the experiment had 3 hectares, where each plot consisted of 1 ha. It was evaluated plant height, stem diameter and canopy, stem basal area, the relationship between height and stem diameter, the relationship between height and canopy diameter and stem volume. Data were subjected to analysis of variance and compared by Tukey test at 5\% probability. Irrigation systems and dripping sprinkle provide greater plant height, stem diameter, canopy diameter, stem basal area and stem volume.
\end{abstract}

KEYWORDS: Eucalyptus spp., sprayer, dripping irrigation, evapotranspiration.

\section{DESENVOLVIMENTO INICIAL DE DOIS HÍBRIDOS DE EUCALIPTO SUBMETIDOS À IRRIGAÇÃO}

RESUMO: O eucalipto oferece diversas vantagens em comparação a outras espécies florestais, e utilizando a irrigação localizada pode aumentar a produtividade e diminuir o tempo de produção. Objetivou-se pelo presente estudo avaliar dois híbridos de eucalipto (Grancam e Urograndis), sem irrigação e irrigados por gotejamento e microaspersão aos 90; 120; 150 e 180 dias após transplante (DAT). O experimento foi instalado na área experimental de irrigação da Universidade Estadual de Mato Grosso do Sul, no município de Aquidauana-MS. O delineamento experimental foi o de blocos casualizados, em parcelas subdivididas, com quatro blocos e duas replicações dentro de cada bloco, sendo que as parcelas foram compostas pelos tratamentos de irrigação (gotejamento, microaspersão e sequeiro), e as subparcelas, pelos híbridos (Grancam e Urograndis). Foram avaliadas a altura de plantas, o diâmetro do caule e da copa, a área basal do caule, a relação entre altura e diâmetro do caule, a relação entre altura e diâmetro da copa e o volume do caule. Os dados foram submetidos à análise de variância e comparadas pelo teste de Tukey, no nível de 5\% de probabilidade. Os sistemas de irrigação por gotejamento e microaspersão propiciam maior altura de plantas, diâmetro do caule, diâmetro da copa, área basal do caule e volume de caule.

PALAVRAS-CHAVE: Eucaliptus spp., microaspersão, gotejamento, evapotranspiração.

\footnotetext{
${ }^{1}$ Engenheiro Agrônomo, Doutorando em Agronomia, Bolsista do CNPq, Faculdade de Ciências Agrárias/Universidade Federal da Grande Dourados (FCA/UFGD), Dourados, MS, Fone: (67) 3411.3905, gabrielqo@hotmail.com.

${ }^{2}$ Engenheiro Agrônomo, Professor Adjunto, Universidade Estadual de Mato Grosso do Sul (UEMS), Aquidauana, MS.

${ }^{3}$ Engenheiro Agrônomo, Doutorando em Agronomia, Bolsista CAPES, FCA/UFGD, Dourados, MS.

${ }^{4}$ Acadêmico do Curso de Engenharia Florestal, UEMS, Aquidauana, MS.

Recebido pelo Conselho Editorial em: 9-4-2012
}

Aprovado pelo Conselho Editorial em: 16-3-2013 


\section{INTRODUCTION}

Since 1908 Brazil has been growing eucalyptus and today, 3.5 million hectares of Brazilian land have been covered by planted forests of eucalyptus. Like other exotic cultures, for example coffee, sugarcane and soybeans, some eucalypt species found in the soil and in the Brazilian climate, ideal conditions for production scale, so that practically all major pulp and timber industries of the world are present in Brazil. Allied to the preservation of native forests absorb 196 million tons of carbon from the atmosphere each year, contributing to the reduction of greenhouse effect (QUEIROZ \& BARRICHELO, 2007).

The production of a forest is determined by the amount of solar radiation intercepted by the canopy and the conversion efficiency of this radiation into biomass. This efficiency is primarily influenced by the availability of water and nutrients ((SANTANA et al., 2008).

According to HUBBARD et al. (2010), the rate of expansion of eucalyptus plantations in Brazil is very fast and there is a need for more information on the use of water for these plantations varies according to forest productivity expected, and the intensity of management. The eucalypt culture is planted by almost all the national territory, and in some situations have limitations to the development due to water stress in the soil (VELLINI et al., 2008). According to ALVES (2009), for several reasons, including its hardiness, high cost involved in the implementation of irrigation systems in the dimensions of planting areas, and also for being a traditionally rained culture, there is little information on the crop water requirements of eucalyptus. SILVA et al. (2011) noted that, typically, the plantations are embedded in ecosystems sensitive to human disturbance due to the rugged topography, soils with low fertility and ancient degraded agricultural areas.

According to CARNEIRO et al. (2008b), the reforestation with eucalyptus is still a controversial issue with regard to water consumption and its relation to water availability in the watershed, and the quest for knowledge of the interactions that occur between environmental conditions and gas exchange in the canopy essential in determining the amount of water transpired by these forests.

For better development of human activities related to the rational use of water, it is important the development of irrigation systems more efficient by avoiding wastage of the same (NASCIMENTO et al., 2009). As reported by CUNHA et al. (2009) the efficiency of irrigation for appropriately irrigated area together with the effects associated with the losses by application desuniformity, by percolation, by evaporation and drifting and in the conduction, represented by the distribution efficiency, application and conduction, respectively. According to SOUZA et al. (2003), systems of irrigation is a good option to provide more efficient use of water, in which, depending on the characteristics, the issuers offer different percentage of wetted area (PWA).

The PWA is obtained by the ratio between the width of the strip irrigated defined by the average diameter of the wetted bulb and the spacing between the rows of plants (OLIVEIRA et al., 2009). However BERNARDO et al. (2008) reported that PWA varies depending on soil type, the type of emitter, the emitter spacing and flow rate, the water application time and the applied water sheet. Therefore, it is important for studies of water applications using different irrigation systems, as it may affect differently the behavior of the culture, such as growth and development of the plant.

The objective of the present study was to evaluate two hybrid eucalyptus (Grancam and Urograndis) without irrigation and irrigated by dripping systems and micro sprinkler at 90, 120, 150 and 180 days after transplanting (DAT).

\section{MATERIAL AND METHODS}

The research was conducted at the experimental unit of irrigated agriculture of Aquidauna University - State University of Mato Grosso do Sul (UUA / UEMS), located in the municipality of Aquidauna - MS with geographical coordinates $20^{\circ} 20^{\prime}$ South, $55^{\circ} 48^{\prime}$ West and average altitude of 174 meters. The climate of the region, according to the Köppen classification, was described as Aw, 
defined as sub-tropical hot and humid, with rainy season in the summer and dry in the winter and annual average rainfall of $1200 \mathrm{~mm}$. The soil in the area, according to EMBRAPA (2009), is classified as dystrophic Red Yellow Argyrols. Climatic data were obtained from the meteorological station of the National Institute of Meteorology (INMET) localized in Aquidauna-MS, consisting of daily rainfall data, maximum and minimum temperature, relative humidity, solar radiation and wind speed, between April 20th and October 20th, 2011 (Table 1)

TABLE 1. Average data of maximum, minimum and mean temperature $\left(\mathrm{T}_{\max }, \mathrm{T}_{\min }\right.$ and $\left.\mathrm{T}_{\text {mean }}\right)$ relative humidity $(\mathrm{RH})$, solar radiation(Rs), wind speed at 2 meters tall $\left(\mathrm{U}_{2}\right)$ and rainfall (mm) for the period April 20th to October 20th, 2011 in Aquidauana-MS.

\begin{tabular}{llllllll}
\hline \multirow{2}{*}{ DAT* $^{*}$} & $\mathrm{~T}_{\max }$ & $\mathrm{T}_{\min }$ & $\mathrm{T}_{\operatorname{mean}}$ & $\mathrm{RH}$ & $\mathrm{Rs}$ & $\mathrm{U}_{2}$ & Precipitation \\
\cline { 2 - 7 } & $-------------{ }^{\circ} \mathrm{C}------------$ & $\%$ & $\mathrm{MJ} \mathrm{m}^{2}$ day $^{-1}$ & $\mathrm{~m} \mathrm{~s}^{-1}$ & $\mathrm{~mm}$ \\
\hline 1 a 30 & 29.34 & 17.24 & 23.29 & 71.58 & 16.69 & 0.74 & 52.00 \\
31 a 60 & 29.98 & 15.30 & 22.64 & 65.71 & 14.55 & 1.02 & 8.00 \\
61 a 90 & 29.09 & 14.08 & 21.59 & 65.58 & 16.12 & 1.18 & 16.40 \\
91 a 120 & 29.95 & 15.96 & 22.95 & 60.43 & 16.33 & 1.43 & 30.40 \\
121 a 150 & 33.65 & 17.93 & 25.79 & 53.42 & 20.09 & 1.54 & 37.20 \\
151 a 180 & 33.69 & 20.49 & 27.09 & 61.58 & 21.60 & 1.60 & 130.60 \\
\hline
\end{tabular}

* Days after transplanting.

The nitrogen, potassium and phosphorous, in the planting of seedlings, was conducted from the soil chemical analysis (Table 2) and in accordance with the recommendations of ANDRADE (2004), corresponding to 30 and $40 \mathrm{~kg} \mathrm{ha}^{-1}$ of $\mathrm{P}_{2} \mathrm{O}_{5}$ and $\mathrm{K}_{2} \mathrm{O}$, respectively.

TABLE 2. Chemical characterization of the soil.

\begin{tabular}{lclllllllll}
\hline \multirow{2}{*}{$\begin{array}{l}\text { depth } \\
(\mathrm{m})\end{array}$} & & $\mathrm{P}$ & $\mathrm{O} . \mathrm{M}$. & $\mathrm{K}$ & $\mathrm{Ca}$ & $\mathrm{Mg}$ & $\mathrm{Al}$ & $\mathrm{H}+\mathrm{Al}$ & $\mathrm{SB}$ & $\mathrm{CTC}$ \\
\cline { 3 - 10 } & ${ }^{*} \mathrm{pH}$ & $\mathrm{mg} \mathrm{dm}^{-3}$ & $\mathrm{~g} \mathrm{dm}^{-3}$ & $\mathrm{cmol}_{\mathrm{c}} \mathrm{dm}^{-3}$ & & & & & \\
\hline $0.0-0.2$ & 6.5 & 16.6 & 22.0 & 0.66 & 3.7 & 0.9 & 0.0 & 2.2 & 5.26 & 7.46 \\
$0.2-0.4$ & 6.3 & 12.6 & 13.0 & 0.28 & 3.4 & 0.7 & 0.0 & 2.2 & 4.38 & 6.58 \\
$0.4-0.6$ & 6.2 & 7.3 & 9.0 & 0.16 & 2.6 & 0.6 & 0.0 & 2.0 & 3.36 & 5.36 \\
\hline${ }^{*} \mathrm{pH}$ in water 1:2.5. & & & & & & & & & &
\end{tabular}

On April 19, 2011 were made the pits, where the formulated 04-20-20 was mixed with soil in the amount of $115 \mathrm{~g}$ per plant (127.78 kg ha-1).

Before the implementation of the experiment, the area was previously plowed and conducted to the control of invasive plants, which were desiccated with the application of glyphosate at $4 \mathrm{~L} \mathrm{ha}^{-}$ ${ }^{1}$ of the commercial product containing 360 g i.a. $\mathrm{L}^{-1}$.

The experimental design was randomized blocks, in split plot, using four blocks and two replications within each block. The treatments in the plots correspond to two irrigation systems (dripping and micro) and an area of dryland. In the subplot treatments were the Eucalyptus hybrids, being the Urograndis, clone I224 (Eucalyptus urophilla x Eucalyptus grandis) and Grancam, clone 1277 (Eucalyptus grandis x Eucalyptus camaldulensis).

The experimental area had three hectares (3 ha), being one ha with dripping irrigation system, 1 ha with micro sprinklers irrigation system and 1 ha without irrigation. The seedlings were transplanted to the field on April 20th, 2011, when they had an average height of $30 \mathrm{~cm}$, spaced at $2.25 \times 4.00 \mathrm{~m}$.

The area irrigated by drip emitters was composed of drippers with a flow rate of $2.4 \mathrm{~L} \mathrm{~h}^{-1}, 0.5$ $\mathrm{m}$ spacing between emitters and pressure of $10 \mathrm{~m}$ c.a.. Already, the micro sprinklers was used drippers with unit flow of $48 \mathrm{~L} \mathrm{~h}^{-1}$, an operating range of $1.5 \mathrm{~m}$ and an operating pressure of $40 \mathrm{~m}$ 
c.a. at $30 \mathrm{~cm}$ from each plant.

Each subplot consisted of two experimental units (usable area) with ten plants, whose areas of the experimental units comprised two rows of plants with $11.25 \mathrm{~m}$ long each line, corresponding to $90 \mathrm{~m}^{2}$.

The irrigation management was based on the estimation of the reference evapotranspiration (ETo) from equation (1) of Penman-Monteith (ALLEN et al., 1998):

$$
\text { ETo }=\frac{0.408 \Delta(\mathrm{Rn}-\mathrm{G})+\gamma\left(\frac{900 \mathrm{U}_{2}}{\mathrm{~T}+273}\right)(\text { es - ea })}{\Delta+\gamma\left(1+0.34 \mathrm{U}_{2}\right)}
$$

Where:

ETo - reference evapotranspiration, $\mathrm{mm} \mathrm{day}^{-1}$;

$\mathrm{Rn}$ - Net radiation, $\mathrm{MJ} \mathrm{m}^{-2}$ day $^{-1}$;

$\mathrm{G}$ - heat flow in the soil, $\mathrm{MJ} \mathrm{m}^{-2}$ day $^{-1}$;

$\Delta$ - declination of the saturation curve of water vapor, $\mathrm{kPa}^{\circ} \mathrm{C}^{-1}$;

$\gamma$ - psychrometric constant, $\mathrm{kPa}{ }^{\circ} \mathrm{C}^{-1}$;

$\mathrm{U} 2$ - average wind speed of $2 \mathrm{~m}$ above the ground surface, $\mathrm{m} \mathrm{s}^{-1}$;

$\mathrm{T}$ - average air temperature, ${ }^{\circ} \mathrm{C}$;

$\mathrm{e}_{\mathrm{s}}$ - vapor saturation pressure, $\mathrm{kPa}$;

$\mathrm{e}_{\mathrm{a}}$ - vapor pressure, $\mathrm{kPa}$.

The culture evapotranspiration (ETc) was estimated according to Equation 2, followed by adjustments to localized irrigation calculated according to equation 3 (BERNARDO et al., 2008):

$\mathrm{ETc}=\mathrm{ETo} \mathrm{kc}$

Where:

kc - crop coefficient (0.70 to 0.82) estimated daily for eucalyptus (ALVES, 2009).

$$
\mathrm{ETc}_{\mathrm{Loc}}=\mathrm{ETc}_{\mathrm{L}}
$$

Where:

$\mathrm{ETC}_{\mathrm{Loc}}$ - crop evapotranspiration according to the method of irrigation, $\mathrm{mm} \mathrm{day}^{-1}$;

$\mathrm{k}_{\mathrm{L}}$ - correction factor according to the method of localized irrigation, estimated according to equation 4 (BERNARDO et al., 2008).

$$
\mathrm{k}_{\mathrm{L}}=0.1 \sqrt{\mathrm{PAM}}
$$

Where:

PWA - Percentage of the wetted area calculated according BERNARDO et al. (2008).

The irrigation systems by dripping and micro sprinklers obtained values of PWA of $25.0 \%$ and $78.5 \%$, respectively. To calculate the water sheet was used as a criterion the easily available water for localized irrigation $\left(\mathrm{EAW}_{\mathrm{Loc}}\right)$, which is calculated according to equation 5.

$$
\mathrm{EAW}_{\mathrm{Loc}}=\left(\theta_{\mathrm{fe}}-\theta_{\mathrm{pwp}}\right) \mathrm{Zp} \frac{\mathrm{PMA}}{100}
$$

Where:

$\theta_{\mathrm{fc}}-$ soil moisture at field capacity (matric potential of $-10 \mathrm{kPa}, \mathrm{m}^{3} \mathrm{~m}^{-3}$ );

$\theta_{\mathrm{pwp}}$ - soil moisture in the permanent wilting point (matric potential of $-1500 \mathrm{kPa} \mathrm{m}^{3} \mathrm{~m}^{-3}$ );

$\mathrm{Z}$ - depth of the root system, $970 \mathrm{~mm}$ (REIS et al., 2006);

"p" - factor of soil water depletion for conifers (0.7) as recommended by ALLEN et al. (1998). 
The EAW $_{\text {Loc }}$ was 38.9 and $58.8 \mathrm{~mm}$ for dripping and micro sprinklers. However, the irrigation was performed when the sum of the $\mathrm{ETC}_{\mathrm{Loc}}$ was equal to or greater than $9 \mathrm{~mm}$.

Data collection began at 90 DAT (July 19th, 2011), being held every 30 days up to 180 DAT, which was measured plant height (H), stem diameter (SD) (10 cm from the soil surface) and canopy diameter $(\mathrm{CaD})$. The $\mathrm{CaD}$ and $\mathrm{H}$ were measured with the aid of a measuring tape and converted the unit of measurement in centimeters $(\mathrm{cm})$. The $\mathrm{CaD}$ was measured with a digital caliper, with unit in millimeters (mm) and converted to "cm". With these parameters, it was possible to quantify the stem basal area (BAS), the relation between $\mathrm{H}$ and $\mathrm{CD}$, and the relation between $\mathrm{H}$ and $\mathrm{CaD}$ and the stem volume per plant (SV), which was estimated according to equation 6.

$\mathrm{VC}=\mathrm{ABC} A L T 0,5$

In that,

SV - stem volume, $\mathrm{cm}^{3}$;

SBA - stem basal area at $10 \mathrm{~cm}$ from the soil surface, $\mathrm{cm}^{2}$;

$\mathrm{H}$ - plant height, $\mathrm{cm}$;

0.5 - form factor eucalyptus (VILAS BOAS et al., 2009).

With those data, it was performed analysis of variance for each parameter. For those who showed significant effect of the treatments by the $\mathrm{F}$ test, it was proceeded the Tukey mean comparison test at 5\%, using the Statistical Analysis Systems software.

\section{RESULTS AND DISCUSSION}

The total water sheet (rainfall + irrigation) applied during the experiment were 518.13, 448.38 and $270.60 \mathrm{~mm}$ for managements with micro sprinklers irrigation, dripping irrigation and dryland systems, respectively, and the rainfall corresponded to $270.6 \mathrm{~mm}$ (Table 3). It was observed that, in this period, the total depth (TD) for eucalyptus micro sprinklers irrigation system was $13.46 \%$ higher than the one irrigated by dripping and $47.77 \%$ higher than in the dryland and the TD of the irrigated eucalyptus by dripping was 39.65\% higher than the dryland eucalyptus.

TABLE 3. Estimation of evapotranspiration maximum, average, minimum and accumulated (ETc) of eucalyptus, irrigation depth (ID), total depth (TD) and medium irrigation frequency (IF) during the 180 DAT in Aquidauana-MS.

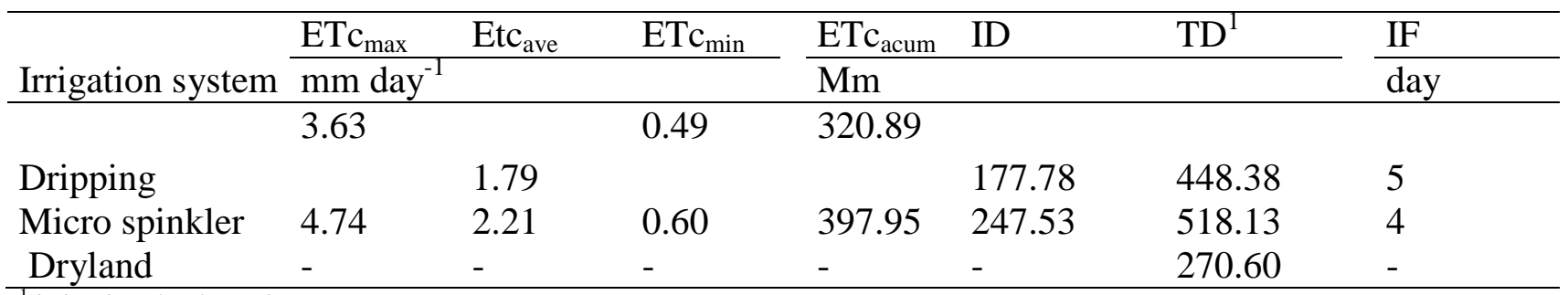

${ }^{1}$ irrigation depth + rain.

The accumulated evapotranspiration of the culture (ETc) for micro sprinklers and dripping irrigation system was 397.95 and $320.89 \mathrm{~mm}$, respectively. The maximum Etc for the micro sprinklers $(4.74 \mathrm{~mm})$ and dripping $(3.63 \mathrm{~mm})$ system were detected at 137 DAT. However, the average ETc until the period evaluated (180 DAT) was $19.00 \%$ higher for the micro sprinklers irrigation system in relation to dripping (Table 3). Precipitation and evapotranspiration of the culture with micro sprinklers system $\left(\mathrm{ETC}_{\mathrm{mic}}\right)$ during the study period, shows that $\mathrm{ETC}_{\text {mic }}$ was always above the evapotranspiration crop with the dripping system (ETC drip) (Figure 1). This can be explained by the fact that the percentage of wetted area (PWA) in the micro sprinklers system is higher (78.5\%) and, therefore, the process of water loss by evaporation at the soil surface is more pronounced than in the dripping system, once that the PWA of the irrigated area by dripping was 25\%. A study conducted in the state of Espirito Santo, HUBBARD et al. (2010) found that annual 
transpiration of Eucalyptus was lower in the treatment of dryland (1394 mm) versus the irrigated $(1779 \mathrm{~mm})$, where this perspiration was responsible for approximately $67 \%$ of the annual rainfall in the dryland treatment and approximately $58 \%$ of the precipitation added to the irrigation in the irrigated treatments.

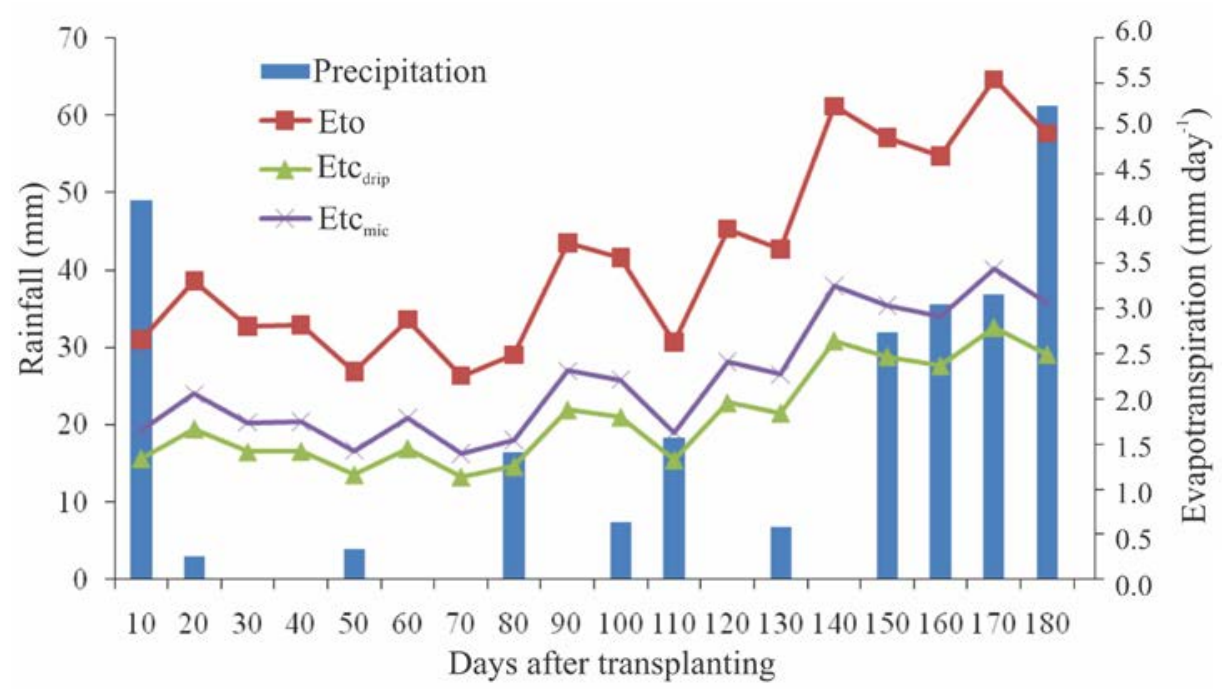

FIGURE 1. Rainfall, reference evapotranspiration (ETo), eucalyptus crop evapotranspiration irrigated by dripping $\left(\right.$ Etc $\left._{\text {drip }}\right)$ and eucalyptus crop evapotranspiration irrigated by micro sprinklers $\left(\mathrm{ETC}_{\mathrm{mic}}\right.$ ) Aquidauana-MS,Brazil, 2011.

TABLE 4. Plant height (H), stem diameter (SD), canopy diameter (CaD), the stem basal area (SBA), the relationship between $\mathrm{H}$ and SD (RHSD), the relationship between $\mathrm{H}$ and $\mathrm{CaD}$ (RHCaD) and stem volume (SV) of eucalyptus for irrigation systems in Aquidauana-MS, 2011.

\begin{tabular}{|c|c|c|c|c|c|c|c|}
\hline \multirow{2}{*}{ Irrigation system } & $\mathrm{H}(\mathrm{cm})$ & $\mathrm{SD}(\mathrm{cm})$ & $\mathrm{CaD}(\mathrm{cm})$ & $\operatorname{SBA}\left(\mathrm{cm}^{2}\right)$ & RHSD & RHCaD & $\mathrm{SV}\left(\mathrm{cm}^{3}\right)$ \\
\hline & \multicolumn{7}{|c|}{90 days after transplanting in the soil } \\
\hline Dripping & $55.00 \mathrm{a}$ & $0.726 \mathrm{a}$ & $48.34 \mathrm{a}$ & $0.433 a b$ & $76.296 a$ & $1.173 \mathrm{a}$ & $12.841 \mathrm{ab}$ \\
\hline Micro sprinklers & $58.75 a$ & $0.782 \mathrm{a}$ & $50.17 \mathrm{a}$ & $0.521 \mathrm{a}$ & $76.006 \mathrm{a}$ & $1.177 \mathrm{a}$ & $17.709 a$ \\
\hline Dryland & $46.29 \mathrm{~b}$ & $0.613 b$ & $37.69 \mathrm{~b}$ & $0.318 b$ & 78.451a & 1.173a & $8.055 b$ \\
\hline DMS & 6.369 & 0.106 & 6.875 & 0.140 & - & - & 7.329 \\
\hline- & \multicolumn{7}{|c|}{120 days after transplanting in the soil } \\
\hline Dripping & $64.05 \mathrm{ab}$ & $0.894 \mathrm{ab}$ & $58,34 a$ & $0.675 b$ & $72.637 a$ & $1.096 \mathrm{a}$ & $24.31 \mathrm{ab}$ \\
\hline Micro sprinklers & $70.27 \mathrm{a}$ & $1.029 \mathrm{a}$ & $60,79 a$ & $0.905 a$ & $68.922 \mathrm{a}$ & $1.156 \mathrm{a}$ & $37.209 \mathrm{a}$ \\
\hline Dryland & $56.46 \mathrm{~b}$ & $0.823 b$ & $48,85 b$ & $0.573 b$ & $70.268 \mathrm{a}$ & $1.167 \mathrm{a}$ & $18.044 b$ \\
\hline DMS & 8.626 & 0.137 & 8.991 & 0.224 & - & - & 13.694 \\
\hline- & \multicolumn{7}{|c|}{150 days after transplanting in the soil } \\
\hline Dripping & 79.59ab & $1.233 \mathrm{ab}$ & $68.87 a$ & $1.285 \mathrm{ab}$ & $65.855 a$ & $1.187 \mathrm{a}$ & $56.92 \mathrm{ab}$ \\
\hline Micro sprinkler & $85.87 a$ & $1.392 \mathrm{a}$ & 68.93a & $1.677 \mathrm{a}$ & $62.722 \mathrm{a}$ & $1.375 \mathrm{a}$ & $84.86 a$ \\
\hline Dryland & $68.335 b$ & $1.079 \mathrm{~b}$ & $57.84 a$ & $1.031 b$ & $65.791 \mathrm{a}$ & $1.252 \mathrm{a}$ & $41.13 \mathrm{~b}$ \\
\hline DMS & 12.331 & 0.240 & - & 0.501 & - & - & 34.191 \\
\hline- & \multicolumn{7}{|c|}{180 days after transplanting in the soil } \\
\hline Dripping & 101.91a & $1.711 \mathrm{a}$ & $90.38 \mathrm{a}$ & $2.440 \mathrm{a}$ & $59.629 a$ & $1.131 \mathrm{a}$ & $138.24 \mathrm{a}$ \\
\hline Micro sprinkler & $105.13 a$ & $1.778 \mathrm{a}$ & $86.44 a$ & 2.649a & $58.972 \mathrm{a}$ & $1.201 \mathrm{a}$ & 158.32a \\
\hline Dryland & $82.77 \mathrm{~b}$ & $1.432 \mathrm{~b}$ & $68.37 \mathrm{~b}$ & $1.733 \mathrm{~b}$ & 58.204a & $1.211 \mathrm{a}$ & $81.60 \mathrm{~b}$ \\
\hline DMS & 12.041 & 0.212 & 11.774 & 0.539 & - & - & 42.053 \\
\hline
\end{tabular}

Averages followed by the different letters in the columns differ at $5 \%$ probability by Tukey test. 
There was influence on irrigation systems in the parameters evaluated on eucalyptus at 90 , 120,150 and 180 DAT in Aquidauna-MS (Table 4). The H at 90 DAT, with the dripping and micro sprinkle irrigation system had averages of 55.00 and $58.75 \mathrm{~cm}$, respectively, where they did not differ among them, but both differed from the dryland $(46.29 \mathrm{~cm})$.At 120 and 150 DAT, it was observed that the treatment of micro sprinkle achieved the greatest $\mathrm{H}$ average values of 70.27 and $85.87 \mathrm{~cm}$, respectively, however, they did not differ from dripping, in turn, did not differ from the dryland treatment.

It was observed also that the $\mathrm{H}$ at 180 DAT showed the same behavior in the irrigation treatments at 90 DAT (Table 4). The eucalyptus hybrids irrigated by dripping and micro sprinklers and dryland obtained difference in growth of 46.91, 46.38 and $36.48 \mathrm{~cm}$, respectively, from 90 to $180 \mathrm{DAT}$. In general, the irrigation treatments shown to be essential for that the eucalyptus $\mathrm{H}$ in the early stages have significantly higher development than the non-irrigated Eucalyptus for the evaluated periods.

In a study conducted by DREW et al. (2008) with E. globulus, it was found that when there is irrigation, there is root concentration in the soil surface layers, there is a decrease in the matric potential in this layer, however, the root matric potential of the not irrigated trees was relatively high, indicating that the trees were extracting soil water in deeper regions, that is, often the root growth in depth regions is a way of plant defense to water stress (TATAGIBA et al., 2007).

In a study conducted by REIS et al. (2006), who evaluated the development of hybrid clones of Eucalyptus grandis $x$ E. urophylla and of E. camaldulensis $x$ E. spp. subjected to two systems of field irrigation, it was noted that the height growth in an adult eucalyptus, did not vary significantly between treatments for irrigation, while that in diameter and volume was significantly higher in plants of the irrigated treatment compared to non-irrigated.

The SD values for the periods of 90 and 180 DAT were higher with the use of the dripping and micro sprinklers irrigation system over the non-irrigated eucalyptus. For the evaluated periods 120 and 150 DAT, SD was higher with the micro sprinklers compared with the dryland, which, in turn, did not differ from the dripping system (Table 4). In VELLINI et al. (2008) study, it was found that the height growth was proportionally less affected than the diameter growth when decrease the water availability for plants.

Only in the period of 150 DAT there was no significative difference for the $\mathrm{CaD}$ in relation to irrigation treatments. It was found that the $\mathrm{CaD}$ for the period of 90,120 and $180 \mathrm{DAT}$ was superior with irrigation systems when compared with the treatment of dryland. Monitoring the evolution of the $\mathrm{CaD}$ is very important for the planning of irrigated plants, especially in the early stages of development, because it minimizes the effect of the evaporation of water near the stem, where most of the localized irrigation is applied. SILVA et al. (2002) pointed out that the Melaleuca alternifolia Cheel, from 100 days under water deficit occurs reductions in plant height, stem diameter and canopy. According to TAIZ \& ZEIGER (2004) plants in case of water shortage may decrease the development of the canopy causing in a more aggressive deficit, falling leaves by leaf abscission stimulated by the markedly synthesis by greater sensitivity to ethylene.

It can be seen that, at 90 DAT, SBA was higher with the irrigation system of micro sprinklers and smaller with dryland eucalyptus (Table 4). However, the dripping irrigation system was not different from both the other treatments. However, for the same parameter, it is worthy the irrigation system, the 180 DAT were significantly higher compared to non-irrigated eucalyptus and so, it is understood that the replacement of water in relation to crop evapotranspiration is necessary so that one can obtain better results and express their maximum production potential.

Often, the survival of eucalypt below the wilting point is possible only due to its osmotic adjustment, which develops slowly in response to dehydration of the tissue caused by water deficit (TAIZ \& ZEIGER, 2004). 
The SV at 90 DAT showed values in the order of $17.709 \mathrm{~cm}^{3}$, achieved with micro sprinklers irrigation system, and dripping $(12,841 \mathrm{~cm} 3)$ did not differ from the treatment of micro and dryland $(8,055 \mathrm{~cm} 3)$. Table 4 shows that the SV at 120 and 150 DAT had the same statistical behavior to the previous period. At $180 \mathrm{DAT}$, the SV, as well as the parameters $\mathrm{H}, \mathrm{SD}, \mathrm{CaD}$ and SBA, obtained the best results with the use of both irrigation systems, with a difference of SV in relation to eucalyptus dryland of the order of 76.72 and $56,64 \mathrm{~cm} 3$ for micro sprinklers and dripping system, respectively. According to CARNEIRO et al. (2008a), the effect of irrigation delivers moisture between 60 and $90 \mathrm{~cm}$ depth, due to the application of water through dripping system, in which there may be a higher concentration of fine roots in this layer, which are more efficient at extracting soil solution and helping to increase their best development.

According STAPE et al. (2010), although the irrigation cause a significant increase in volume and carbon bole through the majority of the studies, but there is still controversy as quantization of the efficiency in the use of water. Almeida et al. (2007) showed that the efficiency of water use in this species varies dramatically with the leaf area index and stand age.

Comparing the SV in this study, it is clear that initially the developments of eucalyptus hybrids on the effect of irrigation are higher than dryland eucalyptus. Due to the fact that this study took place during 180 DAT, it is suggested that the forthcoming evaluations quantify the availability of soil water front the efficiency of water use in the cultivation of eucalyptus.

Observe that, for all periods, H, SD, CaD, SBA and SV of the Grancam hybrid was significantly higher than the Urograndis (Table 5). These results indicate that the evaluated parameters are strongly linked to a genetic character. REIS et al. (2006), the Grancam hybrid tended to higher height, diameter and volume in the non-irrigated system, different behavior in relation to Urograndis hybrid, whose growth has tended to be higher in the irrigated treatment. However, these same authors explained their higher growth under water stress, the fact that the Grancam hybrid has depth root $(0.97 \mathrm{~m})$ and the highest proportion of biomass allocated to the root system (25.94\%).

TABLE 5. Plant height (H), stem diameter (SD), canopy diameter (CD), the stem basal area (SBA), the relationship between $\mathrm{H}$ and SD (RHSD), the relationship between $\mathrm{H}$ and $\mathrm{CaD}$ (RHCaD) and stem volume (SV) for eucalyptus hybrid, Aquidauana-MS, 2011.

\begin{tabular}{|c|c|c|c|c|c|c|c|}
\hline \multirow{3}{*}{ Hybrid } & $\mathrm{H}(\mathrm{cm})$ & $\mathrm{SD}(\mathrm{cm})$ & $\mathrm{CaD}(\mathrm{cm})$ & SBA $\left(\mathrm{cm}^{2}\right)$ & RHSD & RHCaD & $\mathrm{SV}\left(\mathrm{cm}^{3}\right)$ \\
\hline & & & & & & & \\
\hline & \multicolumn{7}{|c|}{90 Days after transplantation } \\
\hline Grancam & $61.88 a$ & $0.8328 a$ & $54.612 \mathrm{a}$ & $0.570 \mathrm{a}$ & $74.900 a$ & $1.140 \mathrm{~b}$ & $19.093 a$ \\
\hline Urograndis & $44.82 \mathrm{~b}$ & $0.5811 \mathrm{~b}$ & $36.188 \mathrm{~b}$ & $0.279 \mathrm{~b}$ & 78.935a & $1.286 \mathrm{a}$ & $6.644 \mathrm{~b}$ \\
\hline- & \multicolumn{7}{|c|}{120 Days after transplantation } \\
\hline Grancam & $77.10 \mathrm{a}$ & $1.0992 \mathrm{a}$ & 63.159a & $0.993 a$ & $70.761 \mathrm{a}$ & $1.236 \mathrm{a}$ & $41.358 \mathrm{a}$ \\
\hline Urograndis & $50.09 \mathrm{~b}$ & $0.7308 \mathrm{~b}$ & $48.838 \mathrm{~b}$ & $0.442 b$ & $70.458 \mathrm{a}$ & $1.043 \mathrm{~b}$ & $11.684 \mathrm{~b}$ \\
\hline- & \multicolumn{7}{|c|}{150 Days after transplantation } \\
\hline Grancam & 93.43a & $1.5031 \mathrm{a}$ & $71.573 a$ & $1.864 a$ & $62.982 \mathrm{a}$ & $1.365 a$ & $94.120 \mathrm{a}$ \\
\hline Urograndis & $62.43 \mathrm{~b}$ & $0.9663 \mathrm{~b}$ & $58.848 \mathrm{~b}$ & $0.799 b$ & $66.596 a$ & $1.178 \mathrm{a}$ & $27, .820 \mathrm{~b}$ \\
\hline- & \multicolumn{7}{|c|}{180 Days after transplantation } \\
\hline Grancam & $114.04 \mathrm{a}$ & $1.9110 \mathrm{a}$ & $94.312 \mathrm{a}$ & $2.982 \mathrm{a}$ & $59.762 a$ & $1.2165 \mathrm{a}$ & $182.521 \mathrm{a}$ \\
\hline Urograndis & 79.17b & $1.3690 \mathrm{~b}$ & 69.148b & $1.566 \mathrm{~b}$ & 58.108a & $1.1456 b$ & 69.580b \\
\hline
\end{tabular}

Table 5. in all periods, showed no difference, and the RHCaD got no significant effect on the period of 150 DAT. Now for at 180 DAT, the Grancam hybrid (1.2165) significantly outperformed the average Urograndis (1.1456). 
The interaction between irrigation and hybrid factor was found only for the $\mathrm{CaD}$ and $\mathrm{RHCaD}$ to the 150 DAT (Table 6). It is observed that for SD, the Grancam hybrid was higher than Urograndis when they were subjected to irrigation, both dripping and for micro sprinklers and also there was no difference when they were not irrigated. Irrigation within subplots influenced only the $\mathrm{CaD}$ Grancam hybrid, showing that irrigation systems were superior to dryland. According to SANTANA et al. (2008) the eucalyptus in its early stages of development have canopy more sensitive to interventions through management techniques, reporting that its stability occurs between three years and six months to five years.

TABLE 6. Breakdown of mean canopy diameter (CaD) and the relationship between plant height and Canopy diameter (RHCaD) of the factors of irrigation systems and eucalyptus hybrid to 150 DAT in Aquidauana-MS, 2011.

\begin{tabular}{|c|c|c|c|c|}
\hline \multirow{3}{*}{ Irrigation system } & \multicolumn{4}{|l|}{ Hybrids } \\
\hline & Grancam & Urograndis & Grancam & Urograndis \\
\hline & \multicolumn{2}{|l|}{$\mathrm{CaD}(\mathrm{cm})$} & \multicolumn{2}{|l|}{ RHCaD } \\
\hline Dripping & 76.602aA & 61.129aB & $1.3143 a \mathrm{~A}$ & $1.0612 \mathrm{bB}$ \\
\hline Micro sprinkle & 81.503aA & 56.358aB & $1.232 \mathrm{aB}$ & $1.517 \mathrm{aA}$ \\
\hline Dryland & $56.613 \mathrm{bA}$ & 59.056aA & $1.5489 \mathrm{aA}$ & $0.9557 \mathrm{bB}$ \\
\hline
\end{tabular}

Means followed by different letters, lowercase and uppercase letters in the columns in the row, differ at 5\% probability by Tukey test. Grancam = Eucalyptus grandis $x$ E. camaldulensis; Urograndis = E. urophilla $\times$ E. Grandis.

It was observed that the unfolding of the RHCaD for irrigation treatments did not differ among themselves with the Grancam hybrid. However, with the Urograndis hybrid was found that the micro sprinklers provided higher RHCaD (1.517).

With dripping irrigation and dryland observed that the RHCaD of the Grancam hybrid was significantly higher than Urograndis. For the micro sprinklers irrigation, the RHCaD was higher with Urograndis (Table 6).

\section{CONCLUSIONS}

Throughout the early development of the eucalyptus hybrid: Grancam and Urograndis in Aquidauna-MS, the irrigation systems by dripping and micro sprinklers provide greater plant height, stem diameter, canopy diameter, basal area and stem volume. By 180 days after transplant, irrigated treatments promote medium difference in volume of the stem in relation to dryland on the order of $66.68 \mathrm{~cm}^{3}$.

The Grancam hybrid in early stage of development presents the dendrometric parameters superior to Urograndis.

\section{REFERENCES}

ALLEN, R. G.; PEREIRA, L. S.; RAES, D.; SMITH, M. Crop Evapotranspiration: guidelines for computing crop requirements. Roma: FAO, 1998. 301 p.

ALMEIDA, A.C., SOARES, J.V., LANDSBERG, J.J., REZENDE, G.D. Growth and water balance of Eucalyptus grandis hybrid plantations in Brazil during a rotation for pulp production. Forest Ecology and Management, Amsterdam, v. 251, p. 10-21, 2007.

ALVES, M.E.B. Disponibilidade e demanda hídrica na produtividade da cultura do eucalipto. 2009. 136 f. Tese (Doutorado em Meteorologia Agrícola) - Universidade Federal de Viçosa, Viçosa, 2009. 
ANDRADE, L.R.M. Corretivos e fertilizantes para culturas perenes e semiperenes. In: SOUSA, D. M. G.; LOBATO, E. Cerrado, correção do solo e adubação. 2. ed. Brasília: EMBRAPA, 2004. p. 317-366.

BERNARDO, S.; SOARES, A.A.; MANTOVANI, E.C. Manual de irrigação. 8 ed.Viçosa: UFV, 2008. $625 \mathrm{p}$.

CARNEIRO, R.L.C.; RIBEIRO, A.; HUAMAN, C.AM.; LEITE, F.P.; SEDIYAMA, G.C.; BASTOS, N.F. Consumo de água em plantios de eucalipto: Parte 1 Determinação da condutância estomática em tratamentos irrigado e não-irrigado. Revista Árvore, Viçosa-MG, v. 32, n. 1, p. 1-10, 2008a.

CARNEIRO, R.L.C.; RIBEIRO, A.; HUAMAN, C.AM.; LEITE, F.P.; SEDIYAMA, G.C.; NEVES, J.C.L. Consumo de água em plantios de eucalipto: Parte 2 Modelagem da resistência estomática e estimativa da transpiração em tratamentos irrigados e não-irrigados. Revista Árvore, Viçosa-MG, v. 32, n. 1, p. 11-18, 2008b.

CUNHA, F.F.; ALENCAR, C.A.B.; VICENTE, M.R.; BATISTA, R.O.; SOUZA, J.A.R. Comparação de equações para cálculo da uniformidade de aplicação de água para diferentes sistemas de irrigação. Engenharia na agricultura, Viçosa-MG, v. 17, n.5, p. 404-417, 2009.

DREW, D.M; O’GRADY, A.P.; DOWNES, G.M.; READ, J.; WORLEDGE, D. Daily patterns of stem size variation in irrigated and unirrigated Eucalyptus globulus. Tree Physiology, Victoria, v. 28, p. 1573-1581, 2008.

EMBRAPA. Empresa Brasileira de Pesquisa Agropecuária. Sistema brasileiro de classificação de solos. Rio de Janeiro: Centro Nacional de Pesquisa de Solos/Embrapa Solos, 2009. 412 p.

HUBBARD, R.M.; STAPE, J.; RYAN, M.G.; ALMEIDA, A.C.; ROJAS, J. Effects of irrigation on water use and water use efficiency in two fast growing Eucalyptus plantations. Forest Ecology and Management, Amsterdam, v. 259, p. 1714-1721, 2010.

NASCIMENTO, J.M.S.; LIMA, L.A.; CARARO, D.C.; CASTRO, E.M. SILVA, M.V.G. Avaliação da uniformidade de aplicação de água em um sistema de gotejamento para pequenas propriedades. Ciência e Agrotecnologia, Lavras, v. 33, p. 1728-1733, 2009.

OLIVEIRA, L.F.C.; OLIVEIRA, R.Z.; PORTES E CASTRO, T.A. Comportamento fisiológico de cafeeiros submetidos a diferentes disponibilidades de água no solo. Bioscience Journal, Uberlândia, v. 25, n. 3, p. 83-91, 2009.

QUEIROZ, L. R. S.; BARRICHELO, L. E. G. O eucalipto - Um século no Brasil. São Paulo: Neoband Soluções Gráficas, 2007. 127 p.

REIS, G.G.; REIS, M.G.F.; FORTAN, I.C.I.; MONTE, M.A.; GOMES, A.N.; OLIVEIRA, C.H.R. Crescimento de raízes e da parte aérea de clones de híbridos de Eucalyptus grandis X Eucalyptus urophylla e de Eucalyptus camaldulensis X Eucalyptus spp submetidos a dois regimes de irrigação no campo. Revista Árvore, Viçosa-MG, v.30, n.6, p.921-931, 2006.

SANTANA, R.C.; BARROS, N.F.; LEITE, H.G.; COMERFORD, N.B.; NOVAIS, R.F. Estimativa de biomassa de plantios de eucalipto no Brasil. Revista Árvore, Viçosa-MG, v.32, n.4, p.697-706, 2008.

SILVA, M.A.; SILVA, M.L.N.; CURI, N.; AVANZI, J.C.; LEITE, F.P. Sistemas de manejo em plantios florestais de eucalipto e perdas de solo e água na região do Vale do Rio Doce, MG. Ciência Florestal, Santa Maria, v. 21, n. 4, p. 765-776, 2011.

SILVA, S.R.S.; DEMUNER, A.J.; BARBOSA, L.C.A.; CASALI, V.W.D.; NASCIMENTO, E.A.; PINHEIRO, A.L. Efeito do estresse hídrico sobre características de crescimento e a produção de óleo essencial de Melaleuca alternifolia Cheel. Acta Scientiarum, Maringá, v. 24, n. 5, p. 13631368, 2002. 
SOUZA, M.J.H.; RAMOS, M.M.; SIQUEIRA, D.L.; COSTA, L.C.; LHAMAS, A.J.M.; MANTOVANI, E.C.; CECON, P.R.; SALOMÃO, L.C.C. Produção e qualidade dos frutos da limeira ácida 'Tahiti' submetida a diferentes porcentagens de área molhada Revista Brasileira de Engenharia Agrícola e Ambiental, Campina Grande, v.7, n.2, p.245-250, 2003.

STAPE, J.L., BINKLEY, D., RYAN, M.G., FONSECA, S., LOOS, R., SILVA, S., HAKAMADA, R.E., TAKAHASHI, E.N., SILVA, C.R., FERREIRA, J.M., LIMA, A.M., LEITE, F.P., ANDRADE, H., BRANCO, G.C., GAVA, J.L., ALVES, J.M. Influence of water, nutrients and stand structure on wood production in the eight sites of the Brazil Eucalyptus Potential Productivity Project. Forest Ecology and Management, Amsterdam, v. 259, p. 1684-1694, 2010.

TAIZ, L.; ZEIGER, E. Fisiologia vegetal. 3. ed. Porto Alegre: Artmed, 2004. 719p.

TATAGIBA, S.D.; PEZZOPANE, J.E.M.; REIS, E.F. Avaliação do crescimento e produção de clones de Eucaliptus submetidos a diferentes manejos de irrigação. Cerne, Lavras, v. 13, n. 1, p. 19, 2007.

VELLINI, A.L.T.T.; PAULA, N.F.; ALVES, P.L.C.A.; PAVANI, L.C.; BONINE, C.A.V.; SCARPINATI, E.A.; PAULA, R.C. Respostas fisiológicas de diferentes clones de eucalipto sob diferentes regimes de irrigação Revista Árvore, Viçosa-MG, v.32, n.4, p.651-663, 2008.

VILAS BÔAS, O.; MAX, J.C.M.; MELO, A.C.G. Crescimento comparativo de espécies de Eucalyptus e Corymbia no município de Marília, SP. Revista do Instituto Florestal, São Paulo, v. 21, n. 1, p. 63-72, 2009. 